\title{
CONSIDERAÇÕES SOBRE UMA CONCEPÇÃO CRÍTICO-DIALÉTICA E ALTERNATIVA DO DIREITO
}

\author{
Jeferson Fernando Celos \\ Bacharel e Mestrando em Direito pela Unesp-Franca e membro do Núcleo de Estudos de Direito \\ Alternativo da Unesp Franca (NEDA), Diretor do Instituto Práxis de Educação e Cultura.
}

RESUMO: O presente artigo busca delinear algumas características de uma concepção crítico-dialética e alternativa do Direito. Tal concepção vem sendo debatida no âmbito do Núcleo de Estudos de Direito Alternativo, do qual o autor é membro. Por esta concepção entende-se que o Direito é um fenômeno dinâmico e complexo. Dinâmico porque está inserido no processo histórico, na base material da sociedade, numa percepção dialética. Complexo porque é formado por várias dimensões: social, política, normativa, ética, econômica, cultural; é um fenômeno pluridimensional, e não meramente normativo. A simples promulgação de normas não cria direitos, estes são criados nas lutas sociais. $O$ "direito é, enquanto é sendo"; não é sendo lá no código, apenas. Ele é sendo do jeito que os homens e mulheres fizerem com que ele seja. $O$ Direito não está contido única e exclusivamente na lei estatal. A lei, inclusive pode conduzir o "antidireito", o torto, podendo, ainda, ser atuada enquanto instrumento de conservação e de opressão. Mas, defende-se que o Direito também pode ser atuado enquanto instrumento de transformação social - que não virá somente pelas vias estreitas do Direito. Assim, pugna-se por um saber-agir diferenciado, pautado pela dialeticidade, interdisciplinaridade, pluralidade, criatividade, pela radicalidade democrática, pelo caminhar junto com outros atores sociais. Uma práxis insurgente, que nasce e se constrói a partir das contradições da sociedade, e se revela como contestatória, inserindo-se nos marcos de uma luta por uma outra sociedade, outras relações construídas na base da libertação, da ética da alteridade e da justiça material.

PALAVRAS-CHAVE: Direito; Direito Alternativo; Teoria Crítica; Transformação Social; Teoria do Direito; Práxis 
"Ninguém liberta ninguém; ninguém se liberta sozinho. Os homens são libertados em comunhão, mediatizados pelo mundo".

Paulo Freire

\section{INTRODUÇÃO}

O presente artigo insere-se num esforço de demonstrar a legitimidade, a especificidade e a necessidade de uma reflexão crítico-dialética e alternativa do Direito, que substancie uma ação prática, constituindo-se em autêntica práxis social transformadora.

Essa concepção diferenciada vem sendo desenvolvida no âmbito do Núcleo de Estudos de Direito Alternativo da Unesp Franca (NEDA), e é fruto da leitura de vários autores, influenciada por diversas correntes e por diversas práticas. Ela não despreza o que já foi construído em termos de reflexões sobre o fenômeno jurídico, mas afirma que ainda há muito para ser construído.

Assim, procura-se entender o que é o Direito, qual sua finalidade, para que e para quem ele serve e qual o papel dos juristas nesse contexto. Em suma, busca-se entender o que é a realidade social "Direito".

Cumpre-se ressaltar, que nenhuma teoria, sistema de pensamento ou filosofia nasce ao acaso, do nada. Esses fenômenos são produtos do agir humano, sendo construídos por homens e mulheres de carne e osso, em um determinado espaço-tempo, para responder às necessidades colocadas nesse, ou naquele contexto. Torna-se imprescindível uma reflexão contextualizada do Direito, inserindoo na realidade na qual ele nasce e vai ser aplicado, visando estabelecer um diálogo com o real, com o concreto. O contexto sobre o qual se debruça, portanto, é o da América Latina, em termos gerais, e o brasileiro, especificadamente.

A América Latina é uma região do globo terrestre que, à exceção de Cuba, está submersa no capitalismo periférico. Em decorrência de um processo de colonização predatório e de exploração, a América Latina foi vitima, desde os primórdios, de uma situação de subdesenvolvimento, marginalização e dominação. Desigualdades, pobreza, autoritarismo, formas várias de opressão, exclusão e de 
miséria foram sendo incubadas, desenvolvidas e acirradas, até chegar à atual fase do sistema capitalista, marcada pela "globocolonização neoliberal". Os países que integram a região latino-americana não estão no centro do sistema; não estão no "primeiro mundo", onde as decisões são tomadas e onde se usufruem, liberalmente, as benesses desse sistema

Ao lado dessa cruel realidade, vários movimentos e ações de denúncia da tétrica realidade social, bem como de crítica, resistência, enfrentamento, questionamentos e de conflitos foram - e são - gerados, constituindo-se em contundente meio de luta em pelo menos dois planos: demonstrar o inconformismo diante desse estado de coisas; e atuar no sentido da mudança desse quadro, tendo em mira a emancipação e libertação humanas.

O processo de historicidade na América Latina tem sido caracterizado por uma trajetória construída pela dominação interna e pela submissão externa. Trata-se de uma cultura montada a partir da lógica da colonização, exploração, dominação e exclusão dos múltiplos segmentos étnico, religiosos e comunitários. Uma história de contradições, marcada pelo autoritarismo e violência de minorias e pela marginalidade e resistência das maiorias 'ausentes da história', como os movimentos indígenas, negros, campesinos e populares (WOLKMER, 2004, p. 02).

A realidade brasileira não é menos dramática, pois também está sob a influência do modo de produção capitalista - capitalismo periférico - o que produz uma divisão social gritante entre as classes sociais, melhor dizendo, uma divisão injusta e desumana entre os "de cima" e os "de baixo". Vive-se num contexto de extrema desigualdade, de alta concentração de rendas e de terras - onde $1 \%$ dos mais ricos detém quase $50 \%$ da riqueza nacional; o Brasil tem 600 milhões de hectares de terras agricultáveis, tanta terra sem gente e tanta gente sem terra, tanta gente morrendo de fome. Segundo alguns órgãos de pesquisa, 54 milhões de pessoas estão abaixo da linha de pobreza, sendo que destas, 25 milhões são tidas como miseráveis. Exclusão, descaso, miséria, favelas, trabalho escravo e infantil, analfabetismo, latifúndios retratam cotidianamente tal estado de degradação humana. Ocorre a negação diuturna de direitos básicos e do respeito à vida digna a uma parcela historicamente excluída, a comunidade de vítimas para Enrique DUSSEL (Cf 1995, passim). Constata-se muitas vezes que o Direito é utilizado para 
perpetuar esse estado de coisas, sendo verdadeiro obstáculo à transformação social, segundo escreve Eduardo Novoa MONREAL:

...a nota mais deprimente reside em que os preceitos, esquemas e princípios jurídicos em voga se vão convertendo gradualmente, não apenas em um pesado lastro que freia o progresso social, quando não chega, muitas vezes, a levantar-se como um verdadeiro obstáculo para ele (MONREAL, 1988, p. 09).

Aprofundando ainda mais a crítica, pode-se dizer, que muitas vezes o direito é utilizado como um instrumento de conservação social e de dominação. Afirma-se, que a concepção jurídica tradicional e atualmente hegemônica (liberal-individualista e normativo positivista) é incapaz de resolver os problemas da atual sociedade complexa e contraditória - e de operar mudanças/câmbios. Ela é insuficiente, porque não olha a realidade, não enxerga as desigualdades materiais; porque propõe uma generalidade e uma abstração que desconhece o componente ideológico; porque apregoa um todo harmônico e logicamente estruturado, acreditando que o Direito está eqüidistante dos conflitos sociais, e que todos os problemas serão resolvidos pela lei e pelo Estado.

Aqui se coloca, a emergência e legitimidade de uma outra concepção para o direito, um outro saber-fazer (prática em união indissolúvel com a teoria), destacando-se que o Direito desempenha um papel paradoxal: ele pode ser um instrumento histórico de conservação do status quo, mas também pode ser atuado enquanto instrumento de transformação social.

Assim, o Direito pode atuar no sentido da libertação humana, da transformação. Torna-se imperioso buscar uma significação social para o Direito e a responsabilização do jurista enquanto um dos atores da mudança. Esse outro saberfazer deverá ser pautado por uma visão crítico-dialética (conflituosa), interdisciplinar, plural, democrática, criativa, comprometida efetivamente com uma luta por um outro Direito, uma outra sociedade, outras relações sociais, construídas com base na emancipação, na efetivação da dignidade humana, na inclusão e na justiça social. Propugna-se por um direito enquanto práxis insurgente, que nasce e se constrói a partir das contradições da sociedade, articulado com todos os movimentos de crítica e de contestação.

Passa-se agora a demonstrar os fundamentos dessa concepção críticodialética e alternativa - que são vários - concentrando-se a atenção na Teoria 
Crítica do Direito, na abordagem dialética, e encerrando o artigo, com a contribuição de Franca, a respeito do Direito Alternativo e da Condição do Direito.

\section{SOBRE A TEORIA CRÍTICA DO DIREITO}

Os teóricos ligam a crítica ao conceito de crise. GRAMSCI diz que a crise se instala quando o velho morreu e o novo ainda não nasceu. A percepção da crise gera uma angústia e uma visão crítica. Ter uma concepção crítica do Direito significa ter uma visão sobre suas crises: na produção, na aplicação, no ensino, o que vai engendrar o tecnicismo. Há quem perceba essa crise, mas, infelizmente, esses são a minoria.

Uma prática crítica também existe: Direito Alternativo, Direito Achado na Rua, Direito Insurgente, Ministério Público Democrático (MPD), Movimento da Magistratura Fluminense pela Democracia (MMFD), dentre outras. Mas o nível de discussão e investigação crítica no Direito é quase nenhuma.

A definição de teoria em Marx e Engels é um dos antecedentes históricos importantíssimos para a atual configuração da teoria crítica. Para eles, a teoria aparece como crítica revolucionária. Não se propõe a conscientizar os indivíduos, criando uma consciência verdadeira para opô-la à falsa e com isto transformar o mundo. A teoria está encarregada de desvendar os processos reais e históricos nos quais se dá a prática humana. Ela aponta os processos objetivos que perpetuam a dominação e a exploração e almeja apontar aqueles que conduzem à libertação. $A$ teoria não fica encarregada de tomar o lugar da prática, nem de guiá-la, nem de se inutilizar para valorizar apenas a prática. A relação entre elas é dialética e não de subordinação. A teoria nega a prática enquanto prática imediata para revelá-la enquanto práxis social (atividade socialmente produzida); a prática nega a teoria como saber separado, autônomo e acabado, separado do real e que pretende governá-lo (Cf CHAUÍ, 1984, p.81-82).

As fontes teóricas da crítica jurídica são muitas e não vamos encontrar uma definição exclusiva em uma única obra. Não há necessidade rigorosa de se definir um único campo. Existem várias matrizes filosóficas, como a Escola de Frankfurt, a de Michel MIAILLE e a Crítica do Direito Francês, a crítica jurídica brasileira, representada entre outros, por Roberto LIRA FILHO, Roberto AGUIAR, José 
Eduardo FARIA, José Reinaldo Lima LOPES, Luiz Fernando COELHO, Antônio Carlos WOLKMER.

A teoria crítica do Direito sabe dizer muito mais o que o Direito não é, qual método não é adequado. Propõe-se uma atitude desconstrutiva, mas não foi capaz, ainda, de apresentar um outro paradigma crítico, para substituir o velho e defasado paradigma tradicional. Os modelos teóricos estão sempre em construção e vai ser sempre assim, pelo menos não é religião não é dogma.

O pensamento crítico é indefinido, inacabado, inconfortável; as incertezas provocam uma fuga da dogmática. Esse saber tem que aprender a conviver com a retificabilidade e as inseguranças. Pode ser um pouco frustrante, mas delimitar e definir precisamente os aspectos paradigmáticos não é a preocupação central, mesmo com o desconforto psicológico de não se ter uma fórmula pronta. Não dá para enclausurar a realidade numa camisa de força. Os críticos têm um "prazer mórbido" pela indefinição.

Resgata-se a epochè dos gregos, ou seja, a suspensão das conclusões definitivas, suspender os julgamentos. Os críticos têm um pouco de ceticismo, de desapego ao fechamento definitivo das coisas. É o não se dobrar, não se submeter dogmaticamente às verdades tradicionais. A atitude negativa é a de dizer "não concordo"; a positiva é a de perguntar o porquê. Estão com um pé na pósmodernidade (época das verdade, das conclusões, das filosofias, das dúvidas e incertezas). Nunca se terá sossego.

Que papel o Direito exerce nesse contexto de dominação instrumental? Os críticos levantaram as funções de manipulação, dominação, conservação do status quo:

...na verdade a teoria jurídica crítica procura romper com o mito da neutralidade do direito, demonstrando que a interpretação dogmática da lei, de forma supostamente neutra e eqüidistante dos conflitos sociais, nada mais é do que uma servil reprodução dos interesses de classes superiores do ponto de vista socioeconômico, previamente consolidados na norma jurídica (MACHADO, 1999, p. 66).

Adverte-se, porém, que não existe uma teoria crítica geral, acabada e definitiva, lembrando-se ainda, que uma exigência da crítica e da dialética é a autocrítica, que impede o engessamento, a dogmatização, a perenidade, uma visão única, simplista, reducionista e centralizada. Mas é inegável a existência de um 
pensamento crítico significativo, revelando uma insatisfação contra o monopólio da concepção tradicional do direito, legitimada de forma dogmática: lógico-formal, positivista, com pretensão de certeza absoluta e que não permite questionamentos.

Segundo o juiz catarinense Lédio Rosa de ANDRADE:

Queiram ou não os juristas, o Direito não é uma ciência pura, autônoma, um método racional, objetivo, universal e imutável, capaz de garantir segurança, neutralidade e objetividade jurídica, ou seja, permitir ao julgador encontrar, sempre, a única, a verdadeira e justa solução para cada caso concreto. Em lugar de um método perfeito, o Direito é um discurso, uma retórica, buscando convencer os cidadãos do bom uso do poder, da justeza no emprego da violência organizada. Nesse contexto, as decisões jurídicas não possuem fundamentos científicos, não são verdades absolutas, pois são fundamentadas em critérios morais, sociais, econômicos, ou de forma clara, em critérios político-ideológicos (...). E isso não é a desgraça do Direito. Faz parte da dialética social, desde que encarado dessa forma, sem subterfúgios, sem estigmatizações e sem patranhas ideológicas (ANDRADE, 1996, p.20, grifos nossos).

Segundo Antônio Carlos WOLKMER os objetivos de uma crítica do direito se dão em dois planos: no nível teórico e no nível prático. No nível teórico busca-se a denúncia dos mitos e falácias que dão sustentação à ciência tradicional, sendo largamente reproduzidos e aceitos por grande parte dos juristas. No nível da prática visa constituir o direito em um dos instrumentos estratégicos e impulsionadores da efetiva alteração das práticas vigentes, tendo como norte a construção de uma organização social mais justa e democrática. Em suma, pretende-se repensar, dessacralizar e romper com a dogmática lógico-formal hegemônica através de um processo estratégico-pedagógico de esclarecimento: autoconsciência, emancipação e transformação social (Cf WOLKMER, 2001, p. XV, 18 e 21).

Em apertada síntese, a teoria crítica vai dizer que o Direito pode e deve atuar como um instrumento de emancipação - lembrando que isso é uma promessa da modernidade - e que ele não está cumprindo esse papel, uma vez que ele foi deturpado pelo mercado. O diferencial é o agir do Direito como instrumento de transformação e de libertação. Isso foi retomado como um desafio pelos vários movimentos críticos e aponta para o problema da militância, do compromisso, do engajamento do jurista. 


\section{A ABORDAGEM DIALÉTICA}

A forma de abordar a realidade socioeconômica, e conseqüentemente 0 Direito, é pela via da análise de totalidade, pois somente ela - do ponto de vista marxista - permite analisar as singularidades e construir as diversas mediações que possibilitam pensar o humano nas diversas situações por que ele passa econômicas, culturais, sociais, infra e superestruturas políticas. O direito não vive e não existe sozinho.

A realidade é construída a partir de mediações contraditórias. Necessário diferenciar o modo como a realidade aparece, do modo como é concretamente produzia.

...Marx afirma que o método histórico-dialético deve partir do que é mais abstrato ou mais simples ou mais imediato (o que se oferece à observação) percorrer o processo contraditório de sua constituição real e atingir o concreto como um sistema de mediações, de relações cada vez mais complexas e que nunca estão dadas à observação. Trata-se sempre de começar pelo aparecer social e chegar pelas mediações reais, ao ser social. Trata-se também, de mostrar como o ser do social determina o modo como este aparece aos homens (CHAUÍ, 1984, p. 48).

A análise de totalidade coloca a importância da dialética. A dialética é um característico modo de pensar e agir, que parte da realidade contraditória e possibilita que o sujeito compreenda-se como parte integrante dessa realidade e agente colaborador do processo de transformação, através do qual todas as coisas existem. Tem como principais características o espírito crítico e autocrítico e atitude contestatória: "A dialética intranqüiliza os comodistas, assusta os preconceituosos, perturba desagradavelmente os pragmáticos ou utilitários... (KONDER, 2000: 86)”.

O pensamento dialético afirma em compensação, que nunca há pontos de partida absolutamente certos, nem problemas definitivamente resolvidos; afirma que o pensamento nunca avança em linha reta, pois toda verdade parcial só assume sua verdadeira significação por seu lugar no conjunto, da mesma forma que o conjunto só pode ser conhecido pelo progresso no conhecimento das verdades parciais (GOLDMANN, 1991, p. 05-06).

Sujeito e objeto são partes de uma mesma realidade e não estão separados como pretendem os positivistas. Estão unidos numa simbiose indissolúvel. O saberfazer (práxis) transforma constantemente a realidade e conseqüentemente o objeto, 
mas também recebe influência dessa realidade social. É por meio da dialética, que se consegue realizar uma crítica radical do direito, que procura as raízes do problema, através de conexões, interações recíprocas, mudanças qualitativas e luta de contrários. Essa forma de abordagem permite o manejo das idéias de contradição, dinamicidade, superação, transformação.

A partir do marxismo a dialética passou a ser concebida em dois planos: o objetivo, como processo de desenvolvimento de uma realidade, segundo normas que the são próprias ou imanentes, e subjetivo, como a apreensão cognoscitiva desse desenvolvimento (COELHO, 1991, p.43).

Para GRAMSCl: "a visão dialética precisa alagar o foco do Direito, abrangendo as pressões coletivas que emergem na sociedade civil e adotam posições vanguardeiras (apud LYRA FILHO, 1982, p.10-11)", como os sindicatos, setores da igreja, associações profissionais e culturais e outros veículos de engajamento progressista.

\section{A CONTRIBUIÇÃO DE FRANCA: DIREITO ALTERNATIVO E A “CONDIÇÃO DO DIREITO”}

Como já foi dito mais acima, a concepção crítico-dialética e alternativa vem sendo desenvolvida no âmbito do Núcleo de Estudos de Direito Alternativo da Unesp Franca (NEDA).

O NEDA é um núcleo de estudos, pesquisa e extensão orientado - desde sua criação em 12 de junho de 1997-pelo professor e Promotor de Justiça Antônio Alberto Machado, que congrega acadêmicos dos cursos da Faculdade de História, Direito e Serviço Social da Unesp/Franca. O NEDA foi criado como espaço para o estudo e discussão do Direito Alternativo e temas correlatos, sempre através de uma perspectiva crítica, uma abordagem dialética e tendo como base teórica, dentre outros, a Teoria Crítica do Direito.

Além dos estudos, o grupo realiza e participa de eventos em todo país, pesquisas coletivas e desenvolve um trabalho de extensão junto à comunidade de Franca, atuando num bairro da periferia da cidade, o Prolongamento do Jardim 
Santa Bárbara, com a coordenação do Promotor de Justiça Paulo César Correa Borges, e pela professora de psicologia Ana Cristina Nassif Soares

A concepção defendida nos trabalhos e apresentações do grupo vai delinear aquilo que é chamado de Direito Alternativo. A alternatividade refere-se a um duplo aspecto. Em primeiro lugar reivindica-se uma outra forma de se pensar e aplicar o Direito; em segundo lugar, o alter revela o compromisso com o Outro, não qualquer outro, mas com o outro excluído:

.... Direito 'descobre' o Outro, respeita-o e o protege; deixa de representar um instrumento de defesa das classes dominantes para transformar-se no instrumento vivo da humanização da sociedade latino-americana, abrindo-se para o diálogo transformador com o ser negado deste continente (ALMEIDA, 2004, p. 81)

Segundo Leonardo BOFF compromisso com o "mais outro", o outro oprimido:

Aqui encontramos o lugar do nascimento da ética que reside nesta relação de res-ponsabilidade diante do rosto do outro, particularmente do mais outro que é o oprimido. É na acolhida ou na rejeição, na aliança ou na hostilidade para com o rosto do outro que se estabelecem as relações mais primárias do ser humano e se decidem as tendências de dominação ou de cooperação (BOFF, 1999, p. 139).

No que tange aos aspectos teóricos, recorre-se a inúmeros autores, mas projetando sobre suas obras, uma perspectiva crítica. Recorre-se a Kant, por exemplo, para resgatar a distinção entre númeno e fenômeno.

"Númeno é a coisa em si, na sua essência inatingível pelo espírito. Fenômeno é a aparência, a manifestação da coisa (MARQUES NETO, 2001, p.11)". A essência das coisas não é dada a conhecer, ou seja, o ser humano não pode capta-la. “...só podemos, segundo KANT, conhecer fenômenos, e apenas na medida em que estes possam ser apreendido por nossa sensibilidade e ordenados pelo intelecto (MARQUES NETO, 2001, p 11)".

É preciso não vincular a teoria crítico-dialética com Kant, mas sem desprezálo, dir-se-á que o Direito se manifesta como um fenômeno, ele pode ter uma essência, mas na ótica kantiana ninguém conseguirá saber, não importa saber; ninguém nunca conseguirá captar o seu númeno. Deixa-se em aberto, perguntas tais como: o que é o Direito? Qual sua essência? 
Portanto, o Direito é um fenômeno, algo que se manifesta na realidade social; algo que existe. É um fenômeno histórico, factível, real, complexo e dinâmico. É um fenômeno pluridimensional, interdisciplinar, que está dentro do processo histórico, numa percepção dialética. É enquanto é sendo, segundo Roberto LYRA FILHO. Não está pronto e nunca estará.

Mas ele se manifesta, ele está dentro da luta social. O Direito é filho da luta. Luta para colocar direitos no papel; luta para efetivá-los (para KELSEN o direito já está pronto na norma); luta pelo alargamento do foco do Direito (para muitos ou para todos); luta pela manutenção do direito, pois sempre haverá uma contenda para retirar direitos; luta na rua, na sala de aula.

A simples promulgação da norma não cria direitos. Direitos são criados nos embates das forças sociais. Por exemplo, o direito de moradia (art. 6o da Constituição Federal) ainda não é direito, mas um momento do direito, o direito ali não está pronto, ele ainda não se afirmou, não se manifestou, o que pede inúmeras lutas: no legislativo, no judiciário, na sala de aula, na rua, no seio dos movimentos sociais.

Um direito pensado a partir da união indissolúvel do homem que conhece com o objeto (o ser que pensa e o objeto pensado). Sujeito e objeto são partes de uma mesma realidade e não estão separados, como pretendem os positivistas.

$\mathrm{O}$ objeto é complexo. Direito não é só norma (que é a dimensão formal), mas tem outras dimensões materiais (social, econômico, cultural, político, psicológico etc). Existe também uma dimensão ética. A tentativa de realizar análises econômicas, sociológicas, políticas dos fenômenos é arriscada, mas não fazê-la já é um fracasso. Não se pode mais falar de compreensão do fenômeno jurídico sem levar em conta todas as dimensões. Por que privilegiar só a norma? Abstrair o contexto sócio-histórico significa cair na armadilha normativista.

O objeto também é dinâmico, é histórico, dá-se no concreto; muda dentro do processo histórico, por força das lutas sociais, do conflito; é produto da luta. Modelo do conflito, contrário à pacificação, à harmonia, reconhecendo a correlação de forças.

O Direito está dentro do processo histórico. Para bem conhecer o direito, deve-se conhecer o processo histórico no qual ele se insere; compreender o contexto sócio-histórico. Se o objeto, também é complexo, torna-se arriscado 
compreendê-lo com um método só. Não existe um crítico-dialético que diga que o método é único, portanto, ele é múltiplo. Pede-se portanto, uma pluralidade de métodos. Assim, o método também é complexo e dinâmico. Defende-se um método dialético, trans/inter/multidisciplinar. Transdisciplinar porque pede uma fusão de métodos; interdisciplinar porque pede um confronto entre métodos, um uso cruzado; multidisciplinar por propor uma aplicação variada e concomitante de métodos.

O que há de novo nessa proposta, é a sistematização de um discurso fragmentado, em torno de um método e um objeto. É uma tarefa teórica, que não será concluída, mas que busca reunir os discursos e esforços dos críticos, em torno do conceito moderno de ciência. Mas ressalta-se que é uma tarefa em permanente construção.

O Direito nasce de várias fontes. Se ele - Direito - tem várias dimensões (social, normativa, cultural, econômica, política, ética) é porque ele possui várias fontes. O fenômeno homogenético ocorre em vários espaços e não apenas na dimensão formal-estatal. Existem espaços informais de produção normativas, configurando-se o Pluralismo Jurídico.

A concepção aqui defendida vai dizer, ainda, que o Direito também é um fenômeno ideológico, o que permite dizer que nunca existirá uma verdade única. Todo direito é compromissado com algo, defende certos interesses e adquire funções bem nítidas. Coloca-se a legitimidade de uma postura engajada e comprometida com os segmentos historicamente excluídos.

A alternatividade busca uma constante vinculação histórica com a luta pela democratização material, concretização da justiça, inclusão social e compromisso/engajamento com "os de baixo":

Prefira o risco de errar com os pobres a ter a pretensão de acertar sem eles. Conviver com os pobres não é fácil. Primeiro, há a tendência de idealizá-los. Depois, descobre-se que entre eles há os mesmos vícios encontrados nas demais classes sociais. Eles não são nem melhores nem piores que os demais seres humanos. A diferença é que são pobres, ou seja, pessoas privadas injusta e involuntariamente dos bens essenciais à vida digna. Por isso, estamos ao lado deles. Por uma questão de justiça. Um militante de esquerda jamais negocia os direitos dos pobres e sabe aprender com eles (BETTO, 2002, p. 34). 
Para David SANCHEZ RÚBIO “....falar de libertação é apostar por uma determinada concepção de Justiça cuja opção são os pobres (...), as vítimas do sistema social capitalista' (apud WOLKMER, 2004, p. 38)".

A concepção crítico-alternativa encara a desigualdade como aberração que deve ser erradicada (Cf BETTO, 2002, p.34). As gritantes desigualdades sociais pedem um tratamento diferenciado, considerando-se cada caso concreto e não a abstração e generalidade da lei. As desigualdades existentes na sociedade brasileira foram historicamente construídas e podem ser igualmente desconstruídas, exigindose instrumentos, políticas e ações que privilegiem os grupos historicamente excluídos, mas sem deixá-los como meros espectadores ou destinatários, procurando inseri-los num projeto onde figurem enquanto sujeitos de sua transformação.

\footnotetext{
A libertação dos oprimidos deverá provir deles mesmos na medida em que se conscientizam da injustiça de sua situação, se organizam entre si e começam com práticas que visam transformar estruturalmente as relações sociais iníquas. A opção pelos pobres contra a sua pobreza e em favor de sua vida e liberdade (...). não são poucos aqueles que não sendo oprimidos se fizeram aliados dos oprimidos, para junto com eles e na perspectiva deles empenhar-se por transformações sociais profundas (BOFF, 1999, p. 141).
}

Por que o Direito vale? Vale se ele for a expressão legítima de uma sociedade legitima, sem exclusão, sem opressão, que possibilite a vida com dignidade. Vale se ele for a expressão da emancipação, da libertação, material, cultural, política, econômica e somente se ele produzir resultados socialmente justos, não se contentando mais, com a igualdade formal, com as soluções artificiais e superficiais.

"...libertação de tudo que limita ou impede ao homem a realização de si mesmo, de tudo que trava o acesso a sua liberdade ou exercício dela (GUTIÉRREZ, 1976, P. 34)”.

\section{A ação existencial e a condição do Direito.}

Antônio A. MACHADO retoma a liberdade em Cóssio, e antes desse, em Sartre: os homens estão condenados à liberdade. O fazer escolhas provoca angústias. Escolhe-se um determinado uso do Direito, quem estiver conscientes 
disso, senão cair-se-á na queda, na escolha inautêntica, que é a não-escolha, o seguir o que de comum ocorre, o que todos fazem (Cf MACHADO, mimeo, 2004).

O Direito é um fenômeno existencial. É um produto do agir humano, é aquilo que os homens e mulheres fazem com que ele seja e enquanto o fazem. Um direito manifestou-se assim, ou assado, porque homens e mulheres fizeram que ele assim se manifestasse. Depende, portanto, do humano; não é o que Deus fez, não se pode dizer que a culpa foi do legislador que criou uma lei injusta.

A essência do Direito será compreendida a partir da forma como o Direito é atuado. Segundo os existencialistas, a existência precede a essência, esta última nunca está pronta, mas vai sendo construída. O Direito pode manifestar-se de várias maneiras, como instrumento de manutenção do status quo, da conservação, da transformação. Depende do ser humano, expressa ações humanas, que serão de controle, de repressão, emancipação, transformação conforme as pessoas atuem controlando, reprimindo, emancipando, transformando. Em suma, Direito é o que as pessoas de carne e osso fazem com que ele seja. Essa é a condição do Direito. Aqui se insere o compromisso do jurista. O diferencial, portanto, é o agir do Direito como instrumento de transformação social, de emancipação, de libertação, o que aponta, novamente, para o problema do engajamento, da militância. Sempre existe a possibilidade de engajamento num ou noutro sentido.

O horizonte ético-utópico é a inclusão, a justiça social. Mas isso para o NEDA tem nome: é o socialismo. Este é o paradigma político-ideológico dessa "concepção francana".

Antônio A. MACHADO fala da emergência de um novo paradigma políticoideológico pois o liberalismo é uma ideologia política que fracassou, é ineficaz, ilegítimo, não proporciona a liberdade, a emancipação, mas pelo contrário, legou à humanidade a lógica individualista, egoísta e mercadológica (Cf MACHADO, 1999, p.70).

Nada é definitivo, tudo é provisório, à espera de ser dialeticamente construído e reconstruído. Insta-se, portanto, a constituição do novo, do devir (vir a ser), tendo como norte a sociedade socialista, enquanto fenômeno histórico, humano. Um socialismo democrático, mais justo, participativo, libertário. Uma outra sociedade através da ascensão de uma democracia social, pluralista e de massas. Luta-se pela socialização do exercício do poder e pela superação da alienação 
política e exploração econômica, almejando-se um Estado material e não formal de direitos.

O socialismo democrático é um paradigma ideológico e político. Os críticos nem partem, de forma contundente, da crítica marxista (que viu o Direito na modernidade, como instrumento de dominação), mas partem daquilo que Marx apontou, e não ficam só na denúncia da dominação impetrada pelo Direito. Afirmam e defendem que o Direito pode funcionar como meio de mudança, de transformação. Quem vai fazer o Direito funcionar assim? Quem quiser, quem se propor ao engajamento, à mudança e tiver uma visão de mundo socialista.

O diferencial está na maneira de como se usa o Direito, para quê se usa o Direito, para quem. Essa franqueza de dizer tudo isso é uma das inovações das concepções críticas, que opera verdadeiro escancaramento dos elementos ideológicos, dos antagonismos de classes, das visões de mundo, dos interesses por trás das ações. Os pés devem ser colocar no chão. O que vai definir os "lados" serão os fatores ideológicos que estão por trás das ações de cada um. A atitude crítica, portanto, é a que enxerga essas influências.

Resgata-se GRAMSCl e a sua construção sobre os intelectuais orgânicos da conservação e os da transformação, estes últimos também chamados de juristas orgânicos das classes populares, pois funcionam como um organismo, com seus agentes compromissados com a emancipação desses segmentos historicamente excluídos, num verdadeiro compromisso com a alteridade. Alteridade como defesa da subjetividade do outro. Emancipa-se com a alteridade, com o outro e somente se o outro se emancipar. É um outro tipo de solidariedade, com respeito às diferenças é a igualdade nas diferenças - mas sem transformar tais diferenças em fatores de exclusão e opressão.

O compromisso defendido coloca a questão da práxis enquanto ação consciente, crítica e transformadora da realidade capitalista, através do Direito. A transformação, no sentido da inclusão e justiça social colocam o componente ético no Direito. Mas quem vai usar? A concepção crítico-dialética não pode ser generalizada, ela é para aqueles que se propõem um fazer/agir, tendo como norte o socialismo democrático (isso tem que se ramificar em todos os ramos do Direito). Não é para todos, mas para os que optarem. 
Só resta para o ser humano seguir o caminho que melhor the aprouver, agindo com a liberdade que ele possui (Cf MACHADO, 2004, mimeo). A justiça está reservada para os deuses, mas lutar pela justiça, fazer justiça é coisa para as pessoas concretas, de carne e osso. Saber o que é injustiça não é difícil, não é difícil identificar e enxergar as injustiças.

Uma atuação dialética não é a que simplesmente decide em favor do mais fraco, mas aquela que se propõe a superar a desigualdade, destruir a fraqueza, confrontando a desigualdade; é a que propõe o conflito. A ação transformadora é no plano macroscópico e raramente se manifesta no conflito individual. Pode-se ate agir de forma sensibilizada diante da injustiça, mas se não houver a proposta da superação dialética, ela não será transformadora. Uma decisão no caso a caso, freqüentemente, não tem o potencial transformador, dialético, pode-se suavizar a situação, até fazer justiça social, mas não ocorrerá a transformação. Não é diariamente que se faz a prática transformadora, mas diariamente se aplica o Direito na perspectiva da justiça social.

Esta é uma visão que ficará à margem da ordem de uma sociedade burguês-capitalista. Ela vai ser escrachada, vai ser tachada de não-científica, de panfletária, ideológica, mas mantém seu compromisso de confronto, perturbação, de ir contra a ordem capitalista e seu horizonte liberal, propondo um horizonte políticoideológico socialista.

Mas onde entra a proposta existencial? É introduzida com a assertiva de que "o direito é sendo", não é sendo lá no código, um direito de papel. Ele é sendo do jeito que os homens e mulheres fizerem com que ele seja. O Direito é feito em sociedade e com os integrantes dessa; ele é produto de um confronto dialético; ele é dialético. Vai prevalecer o que sair do confronto, do conflito que se instaura no seio da sociedade, entre os mais variados interesses; não é só fazer a lei, ou só brigar pela lei, é muito mais complexo.

O Direito vai existindo da maneira como ele é feito. É um devir, é enquanto é feito, enquanto é sendo. Necessário, portanto, identificar a posição do jurista no fazimento do Direito, se ele é uma construção, os juristas têm o compromisso de ir colocando alguns tijolos (aspecto da responsabilidade).

Direito é liberdade, expressão de condutas livres. Pode ser livremente construído e essa construção se dá num processo real, concreto, numa ação 
consciente e compromissada com algo. O Direito pode existir de várias maneiras, esse existir vai demonstrar a essência dele (isso vem depois da existência, ou seja, a existência precede a essência, como vão dizer os existencialistas). Sua essência será conservadora, se o agir for conservador; transformadora, se o agir for transformador (Cf MACHADO, 2004, mimeo)

Os juristas serão responsáveis por fazer uma das escolhas e com certeza, aqueles que fizerem uma escolha pela transformação do atual estado de coisas, serão atacados, serão mal-compreendidos, serão vítimas de má-fé e preconceitos. Mas este é o preço que se paga, quando se escolhe o caminho do não-usual, do diferente, do questionamento, da transformação, do alternativo.

Mas para haver tal transformação, os juristas não podem estar sozinhos, não podem agir sozinhos, nem utilizar somente instrumentais jurídicos. Assume-se a impossibilidade de realizar-se uma "revolução socioeconômica" pela lei, pela jurisprudência, dentro do gabinete, na sala de aula. As estruturas dessa sociedade não serão mudadas simplesmente pelo Direito, ou pelo Direito Alternativo. Tal movimento pede uma força de pressão social bem maior. Mas considera-se o Direito, o Estado como espaços privilegiados de luta, de reivindicações e até mesmo de mobilização popular e coletiva, mas, no entanto, não são os únicos espaços dessa luta pela radicalização democrática e pela transformação social.

Se o Direito é filho da luta, essa luta deve ser desempenhada por diversos atores, não apenas pelos juristas. A pressão social pelas mudanças advirá dos segmentos historicamente dominantes, ou da comunidade de vítimas - "os de baixo". Nenhuma mudança virá de cima para baixo, pois nenhum grupo hegemônico ou poder dominante é suicida (Cf AGUIAR, 1982, p. 76-79). Defende-se um processo coletivo de mudanças, que englobe profissionais de outras áreas e que coloque o Direito na base material da sociedade brasileira e latino-americana, caminhando com os movimentos sociais populares.

\section{CONSIDERAÇÕES FINAIS}

Existem várias formas de se pensar, encarar e praticar o Direito, que, portanto, não é um discurso único, mas constitui-se de vários discursos. Não existe uma definição oficial e exclusiva do Direito. Ninguém conduz a absoluta verdade. 
Grande parte do "mundo jurídico" e da sociedade em geral, desconhece existência do Direito Alternativo, de seus pressupostos, premissas, de seu conteúdo. Ele ainda é visto com certa incompreensão por parte de alguns, que ora miniminizam o trabalho sério que vem sendo feito, ora caracterizam-no em tom pejorativo: os "moderninhos", os baderneiros, os subversivos, os visionários, os utópicos (no sentido negativo do termo). Aqueles que optam pela concepção do direito aqui tratada, sofrem infindável número de preconceitos, de restrições, de desconfianças, por ignorância, desconhecimento ou absoluta má-fé. A pergunta que sempre vem à tona é a de quantas pessoas já leram algo sério e conseqüente sobre essa temática, ou se já tiveram contato com as práticas de seus militantes? Daí o superficialismo de muitas críticas, que se esperam não sejam barradas, pois sempre existirão os "a favor" e os "contra", tudo dentro dos limites democráticos, mas o que causa espécime são as críticas preconceituosas, infundadas e sem conteúdo.

O que importa registrar, nesse modesto artigo, é que aqui se defende uma opinião, um ponto de vista e uma escolha também é feita. Isto não quer dizer que ela seja a verdadeira, a única, nem que seja a melhor. Mas é esta concepção que vem permitindo - aos membros do NEDA - o exercício da capacidade de se questionar, de se indignar, de pensar outras formas de atuação e reflexão e impede o aparecimento do comodismo e do conformismo. Diante da problemática e absurda realidade social em que se vive, não dá mais para afirmar uma pretensa neutralidade, ou dizer que os juristas não têm nada a ver com isso. Diante de todo o contexto social, econômico e político da atualidade brasileira e latino-americana, uma outra concepção prático-teórica do Direito é possível e cada dia mais urgente e necessária.

\section{REFERÊNCIAS BIBLIOGRÁFICAS}

AGUIAR, Roberto Armando Ramos de. Direito, poder e opressão. São Paulo: Alfa-Ômega, 1982.

ALMEIDA, Dean Fábio Bueno de. América Latina: filosofia jurídica da alteridade. In WOLKMER, Antônio Carlos (Org.). Direitos humanos e filosofia jurídica na América Latina. Rio de Janeiro: Lúmen Júris, 2004.

ANDRADE, Lédio Rosa de. Introdução ao direito alternativo brasileiro. São Paulo: Livraria do Advogado, 1996. 
BETTO, Frei. Dez conselhos para militantes de esquerda. In. Revista caros amigos, vol. 50, ano V, janeiro, 2002, p. 34.

BOFF, Leonardo. Saber cuidar: ética do humano - compaixão pela Terra. 8.ed. Petrópolis, Vozes. 1999.

CARVALHO, Amilton Bueno de. Direito alternativo: teoria e prática. Porto Alegre: Síntese,1998 Direito alternativo em movimento. 3.ed. Niterói: Luam, 1999.

COELHO, Luis Fernando. Teoria crítica do direito. 2.ed. Porto Alegre: Sérgio Antônio Fabris Editor, 1991.

CHAUÍ, Marilena. O que é ideologia. 15.ed. São Paulo: Brasiliense, 1984.

DUSSEL, Enrique D. Filosofia da libertação: crítica à ideologia da exclusão. Tradução de Georges I. Massiat. São Paulo: Paulus, 1995.

GOLDMANN, Lucien. Dialética e cultura. Tradução de Luiz Fernando Cardoso, Carlos Nelson Coutinho e Giseh Vianna Konder. 3.ed. Rio de Janeiro: Paz e Terra, 1991.

GUTIÉRREZ, Gustavo. Teologia da libertação. 2.ed. Petrópolis: Vozes, 1976.

KONDER, Leandro. O que é dialética. 28.ed. São Paulo: Brasiliense, 2000.

LYRA FILHO, Roberto. O que é direito. São Paulo: Brasiliense, 1982.

MACHADO, Antônio Alberto. Ministério Público: democracia e ensino jurídico. Belo Horizonte: Del Rey, 2000.

A condição do direito. Palestra proferida no III Simpósio de Direito Alternativo da Unesp Franca, no dia 20 de maio de 2002.

. Direito alternativo e hermenêutica constitucional. Palestra proferida no Congresso Nacional de Direito Alternativo de Franca, no dia 21 de maio de 2004.

O Direito como liberdade. Franca, 2004. Mimeo.

; GOULART, Marcelo Pedroso. Ministério Público e direito alternativo: o MP e a defesa do regime democrático e da ordem jurídica. São Paulo: Acadêmica, 1992.

MARQUES NETO, Agostinho Ramalho. A ciência do direito: conceito, objeto, método. Rio de Janeiro: Renovar, 2001.

MIALLE, Michel. Uma introdução crítica ao direito. Lisboa: Moraes, 1979.

MONREAL, Eduardo Novoa. O direito como obstáculo à transformação social. Tradução de Gérson Pereira dos Santos. Porto Alegre: Sérgio Antônio Fabris Editor, 1988.

SANTOS, Boaventura de Sousa. Pela mão de Alice: o social e o político na pós-modernidade. 4.ed. São Paulo: Cortez, 1997. 
WOLKMER, Antônio Carlos. Introdução ao pensamento jurídico crítico. 3.ed. São Paulo: Saraiva, 2001.

- Fundamentos da crítica no pensamento político e jurídico latino-americano. In WOLKMER, Antônio Carlos(Org.). Direitos humanos e filosofia jurídica na América Latina. Rio de Janeiro: Lúmen Júris, 2004. 